\title{
中国の伝統的集落における割業の現代化による歴史的景観への影響
}

中国陝西省関中地区堯頭村を事例として

\section{THE MODERNIZATION OF CERAMICS INDUSTRY IN CHINESE TRADITIONAL VILLAGES AND ITS IMPACT ON THE HISTORICAL LANDSCAPE}

Yaotou Village in Guanzhong area of Shaanxi province

\author{
劉羽佳*1, 岡 村 祐*2, 小向 ${ }^{*}{ }^{* 3}$ \\ Yujia LIU, Yu OKAMURA and Hikari KOMUKAI
}

\begin{abstract}
The aim of this paper is to clarify the modernization of the actual status of the pottery industry and its influence on the historical landscape in China by interviewing eight potters and conducting field surveys in Yaotou Village of Shaanxi Province. The elements of the historical landscape for the pottery industry and the modernization of the production environment are investigated; further, their influence on the traditional landscape is analyzed. Then, types, designs, and production methods of products and their influence on the landscape are looked into. In addition, the features of sales methods and distributions and their influence on the landscape are also analyzed.
\end{abstract}

Keywords: Porcelain, Preservation, Clan, Cultural landscape 陶磁器, 保全, 宗族, 文化的景観

\section{1. はじめに}

\section{1 研究の背景}

中国における伝統的集落は、「長い歴史の中で、立地や歴史的建造 物、生業、文化、民俗等の有形・無形の要素に根ざして形成された 集落 ${ }^{2}$ 」)」と定義される ${ }^{1)}$ 。このような集落の保全のため、政府は、「歴 史文化名鎮名村」「中国伝統村落（以下、「伝統的集落」）」等の保護 制度を全国で展開している注2)。また、2019 年 6 月の指導意見 ${ }^{\text {i玉 } 3)}$ では、 集落保全においては、伝統的産業へ着目す心゙きと明記され、農業や 手工業などの生業が有寸る文化遺産の価值が見直されている ${ }^{2)}$ 。

窯業は、地域の自然環境に根ざし、現在まで発展を続けてきた伝 統的産業であり、無形・有形の価值が認められる。陝西省堯頭村は、 唐代から陶磁器（本研究における磁器と砂器の総称）注4) の製造・流 通により栄え、中心部には賑やかな町並みが形成された。堯頭村に おける㪇業は、作陶に関わる施設や人々が暮らす家屋などの有形要 素と、人々の信仰、習慣、風俗等の無形要素にも梁く影響を与えて きた。作陶に関わる施設として、中国北部特有の致洞様式の工房と 饅頭窯が利用され、生産エリアは大規模で窸の数も多く、中国北部 における代表的な民窯であった。2006 年に、堯頭村の窯業の生産技 術は「中国無形文化遺産リスト」に記載されるが、陶磁器の内需は 縮小し、伝統的な形態での窯業は衰退している。結果、堯頭村では、 宰業に関連する文化の消失、伝統的な集落景観の変容、あるいは経
済の低迷といった問題に直面している。従来の集落区域は、県の中 心部へのアクセスが悪く、未だインフラの一部が未整備であるなど の理由から、大半の住民は旧村に隣接寸る新村に居住しているため、 旧村の過疎化は著しく、集落の維持は危機的な状況にある。

\section{2 研究の視点}

伝統的集落としての堯頭村の保全においては、伝統的生業である 致業の再生は欠かせない。その際、窯業の現代化、寸なわち現代社 会の需要に応じた致業のあり方を検討することが重要であり、それ が、歴史的景観にいかなる影響を与えるかを考察する必要がある。

㝨業の現代化について、羽田らは作陶工程、製品、流通・販売の 視点から、「機械化その他の合理化を経験した上で、現代のあり方に 適合しようとする伝統工芸としての陶磁器の変化」と定義した ${ }^{3)}$ 。隼 瀬は、「工芸」における「伝統」とは、単なる模倣ではなく時代に即 した再解釈と創造を行い、「素材」「技術・技法」「用」を維持しながら、 継承・形成されてきたものと論じた ${ }^{4)}$ 。中国・景徳鎮における㝘業再 生の成功事例にみるように、伝統的生業である窯業の再生を進める には、小規模経営の工房での伝統の継承が重要な一方で、現代の生 活スタイルや需要を考慮した個性的なデザインの陶磁器の生産及び 合理的で効率の良い生産手法も重要である ${ }^{5)}$ 。

堯頭村でも、生活スタイルの変化、生産設備の機械化、近年の観 光開発により、㝙業のあり方は変化しつつある。本研究では、既往
*1 東京都立大学大学院都市環境科学研究科観光科学域 博士後期課程 · 修士(環境科学)

*2 東京都立大学大学院都市環境科学研究科観光科学域 准教授・博士(工学)

*3 東京都立大学大学院都市環境科学研究科観光科学域 博士前期課程・学士(観光科学)
Ph.D. Candidate, Dept. of Tourism Science, Tokyo Metropolitan University, M.Env.

Assoc. Prof., Dept. of Tourism Science, Tokyo Metropolitan University, Dr.Eng.

Grad. Student, Dept. of Tourism Science, Tokyo Metropolitan University, B.Tourism Science 
研究で言及されている「経営形態」「技術」「製品」に加えて、歴史 的景観や産業としての発展に重要な「生産環境（空間）」「流通・販売」 も現代化の対象として捉える。

\section{3 研究の目的と論文の構成}

以上の背景を踏まえ、本研究では、中国陝西省澄城県堯頭鎮の堯 頭村を研究対象とし、現在の社会・経済状況下での伝統的窯業の継 承之変化に着目し、陶磁器の生産環境、生産手法・デザイン、流通・ 販売手法の現代化の実態と、それが堯頭村の歴史的景観へ与える影 響を明らかにすることを目的とする。具体的には、2 章では、堯頭村 や堯頭村における致業の概要及び歷史的景観の整理を行い、3 章では 生産環境（経営及び空間面）、4 章では製品の特徵と作陶手法、5 章 では陶磁器の販売・流通手法に関して、各々現代化の実態と歴史的 景観への影響を考察する。

\section{4 調査の方法}

2017 年から 2019 年の間に 4 回の現地調查を行った。2017 年 2 月、 澄城県の規画局と文化局を訪問し、既往の保護発展計画 ${ }^{14)}$ 、堯頭窨 を対象とした「観光計画」、住民と行政が連携して記録した堯頭村 の風習や陶磁器に関する資料 ${ }^{13)}$ を入手した。また、同年 10 月には、 集落の公務員や名望家、住民へのヒアリング調查を行った。2018 年 3 月には、当時操業中の全㝨元 (6 箇所) に対して現地踏査とヒアリ ング調查を行い、窵元敷地の平面構成と作陶工程を記録した。2019 年 2 月には、新規開業の 2 箇所の窯元を含む全 8 箇所の蔩元とその 展示室への現地踏查及びヒアリング調查を行った。

\section{5 既往研究と研究の位置づけ}

本研究に関する既往研究は主に $3 つ$ 視点から整理できる。第一 に、山口ら ${ }^{6)}$ 、丸谷ら ${ }^{7)}$ の羔業を基盤とした伝統的集落の保全に関 する研究があり、作陶工程と集落景観との関係性を解明したが、流通・ 販売等への言及はない。また、中国の伝統的集落を対象とした窯業 の作陶工程・空間を研究は少ない。第二に、致業の現代化について の研究があり、前述の羽田ら ${ }^{3)}$ 、隼瀬 ${ }^{4)} 、$ 方ら ${ }^{5)}$ 、轟ら ${ }^{8)}$ は、伝統の 合理的な継承、宰業の現代化と現代の地域社会との側面を主に考察 したが、作陶空間及び生産環境の現代化と集落保全を含めて扱った 研究はない。第三に、本研究の対象地である堯頭村に関する研究には、 地域の景観の特徴 ${ }^{9)}$ やエコミュージアムの視点 ${ }^{10)}$ 、また、堯頭窯跡 の歴史的価值 ${ }^{11)}$ と陶磁器の芸術的価值 ${ }^{12)}$ を論じたものがあるが、作 陶から流通までの全プロセスを通した考察や、歴史的景観の視点か ら致業を捉えた集落保全に関する研究はまだない。

本研究では、上記の作陶工程と集落保全との関係性及び、窯業の 現代化に関する理論を踏まえ、既往研究が注目する割業の現代化の 視点に、生産環境 (空間) や流通・販売手法も加え、それらが歴史 的景観に及ぼす影響を考察することに新規性を見出だせる。

\section{2 堯頭村の概要}

\section{1 堯頭村の立地と略史}

堯頭村は、県の中心部から約 $10 \mathrm{~km}$ の距離にあり、省都の西安市へ は車で 3 時間半程である (Fig. 1)。古来より流通・往来の要所であり、 集落の中央に位置する「老街」と呼ばれる旧商業地区には街道が通る。 堯頭村は、尾根と谷が縦横無尽に走る黄土高原の中に位置し、集落 が階段状の斜面地に形成されているため、窯洞（ヤオトン）と呼ば れる陝西省北部に多く見られる洞穴式建築が並ぶ注5)。一方、省中部

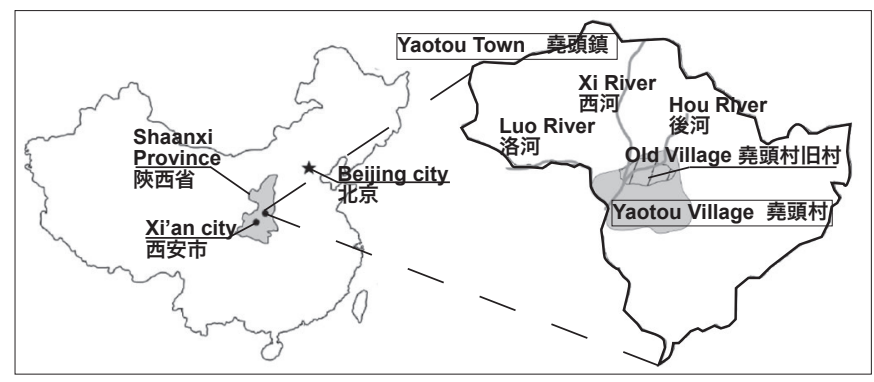

Fig.1 The location of Yaotou village

では中庭型の合院式の空間構成が一般的であり、双方の様式を合わ せた黡洞十合院式という空間構成も顕著である。堯頭村の年間降水 量は少なく、高木の成長や農作物の栽培には不適なため、豊富にあ る黄土や鈗物資源を利用できる致業を生業とし、陶磁器の生産地及 び集散地として発展し、陶磁器の用途・デザインの一部は、地域の 伝統的な食文化や生活習俗との関係も深い。

文献資料 ${ }^{13,14)}$ に拠ると、堯頭村は漢代に興り、早期の人口は少な く、集落北西部の後河沿いに集住した。明代の「澄城県誌」には、 唐代に人口が増加し集落範囲は中央高地一と拡大し、作陶空間と生 活空間が徐々に離れたと記されている。中国全土において窯業が盛 んになる明代嘉靖期 (16 世紀中葉) 及び清代咸豊期（19世紀中葉） に、堯頭村の宰業も繁栄し、清代には磁器の種類が増え、新たな作 陶技術も生まれた。中華民国（1912 1949 年）以降は生活スタイルが 変化し、伝統的陶磁器の需要が落ち込み、生産量が減少した。また、 同時期に石炭採掘が盛しになり、集落の生業は多様化した。1958 年 人民公社の発足により、窯元の家族経営は禁止され、また国営企業 としての県陶磁器生産工場が設立され、伝統的な宗族分担作業制度 はほぼ消失した。1978 年の改革開放以降かつての個人経営の致元は 再開されたが、伝統的な陶磁器の内需縮小により、2000 年前後には 窯元は一箇所のみとなった。県陶磁器生産工場もその頃閉鎖された。 この時期は、窯業の衰退の一方で、人口は 1975 年以降増え続け、多 くの住民は新村へ転出した。集落範囲は、従来の旧村からその東側 及び周辺の新村へと拡大し注6)、旧村の空洞化が進んだ。

2013 年 5 月には、旧村の古窯跡が「全国重点保護単位」注7)に選 定された。近年、農山村集落地域における文化遺産の再評価により、 堯頭村は 2013 年に「伝統的集落」、2014年に「歴史文化名鎮」のリ ストへ記載された。それらを受けて、集落保全事業や観光開発が展 開され、後者の保護計画により、堯頭村旧村全体が核心保護区となり、 かつての周氏、宋氏、杜氏の生活エリア（一部は現在も居住）を含 む生産エリアは遺跡として保護された。また、歴史的町並みとして の老街の建築物や窯業関連施設の整備事業が行われてきた注8)。この ような法制度や事業進展の影響もあり、かつて窯業に従事していた 複数の住民ら（職人含む）が集落へ戻り、窯元を再興している。

\section{2 堯頭村における伝統的な産業としての窯業}

\section{2.1 作陶工程と作陶空間}

堯頭村の葖業の最盛期（明清代）には、集落の中央高地にある老 街を中心に、その南・東側及び北東側には各宗族の生活空間があり、 集落北西部の後河沿いの地域に、生産エリアが広がる。伝統的な作 陶工程と作陶空間が確立されたのもこの時代である。1958 年以前は、 後河周辺の高地で原土を採取し、その近くの沈殿池において川の水 を利用した水䈱が行われた。各作陶区 (2.2.2 で後述) には、窯元が 


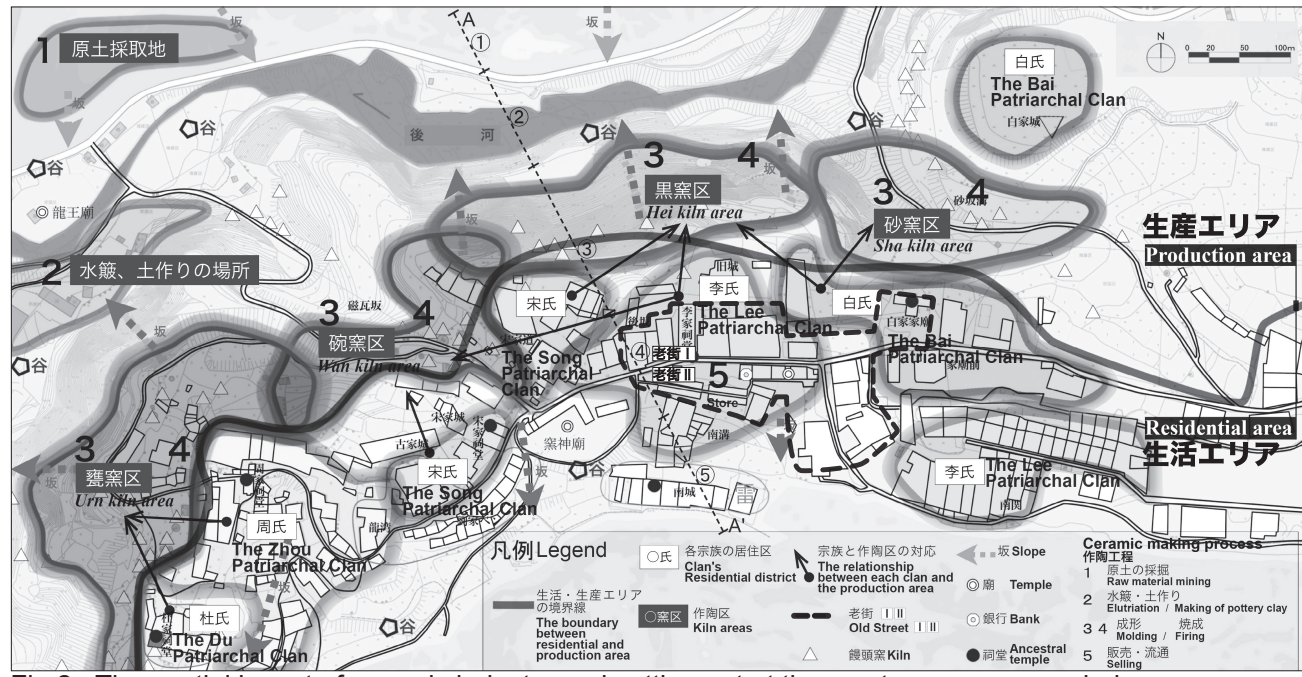

Fig.2 The spatial layout of ceramic industry and settlement at the most prosperous period

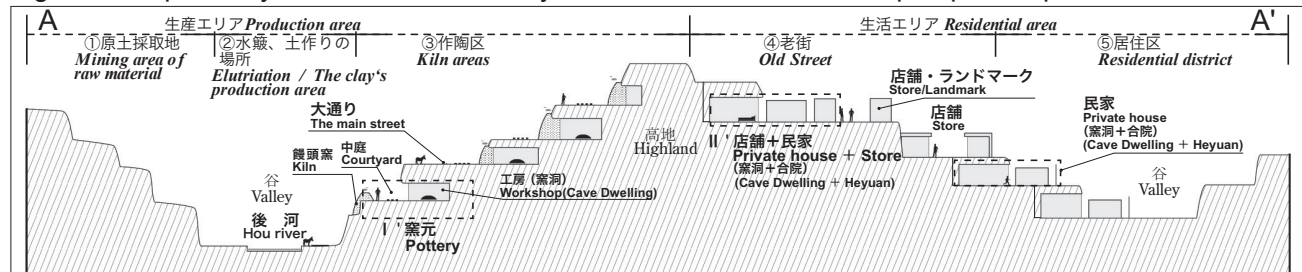

Fig.3 The section view of Yaotou village at the most prosperous period

集積し、各窯元には成形から、乾燥、施釉、焼成までの各工程のた めの工房が備えられていた。工房には、洞穴形式の羔洞が利用された。 その内部の入口左右には成形のためのロクロがあり、装飾や施釉も 工房内または屋外で行われ、主屋の隣に掘られた別の窯洞では、乾 燥が行われた。焼成は、階段状の崖に建てられた丸型の饅頭窯を利 用し、一般的には石炭を燃料として 1250 ～ 1280 度で焼成された ${ }^{\text {注 }}$ 。 以上から、原土の採取地、川、沈殿池、窯洞、乾燥用の空地又は倉庫、 饅頭攽を堯頭村における割業の構成要素として特定することができ る (Photo1)。

\section{2.2 宗族による分担作業制度}

明代に、白氏、李氏が陝西省と隣接する山西省から堯頭村に転入 してきたことで集落は拡大した。また、宗族ごとに担当する作陶工 程や生産可能な陶磁器の種類を制限する宗族分担作業制度はこの時 期に成立し、同時に生産と生活の空間が区分された。前者は、後河 沿いに居住する西坂村村民による原土の採取及び水簸・土作りを行 う空間、そして、宗族毎に分けられた 4 つの作陶区から構成された 注 10)。集落北東側の白氏の白家城城南の窪地付近に砂器を生産する砂 窯区がある。また、老街北側の黒窯区では、李氏、宋氏、白氏によ り小さな壶や香炉等の黒磁器が生産された。これと隣接して、李氏、 宋氏宗族によって民用の茶碗を生産する碗窯区がある。雎窯区は集 落南西側に位置し、龍湾と周家洞の一帯に住んでいる周氏、杜氏に よって大型の水甕が生産された場所である。老街の売店では、宋氏 により陶磁器の販売が行われ、陸運と水運で中国北部へも流通した。 Fig. 2 は、集落の最盛期の状況として「澄城県堯頭歴史文化名鎮保護 計画」に掲載されている「建築実態図」を元に作図したものである $9,10,13,14)$

このように、堯頭村では自然環境に根ざした作業環境が整備され、 生産技術向上と住民の増加及び陶磁器の需要拡大により、窯業は発 展した。また、先述のように宗族分担作業制度は、集落の発展段階

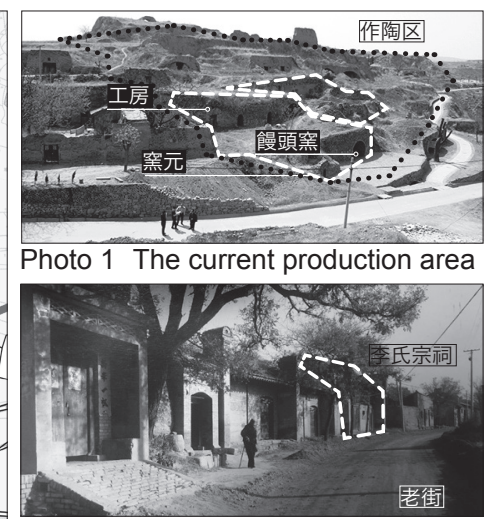

Photo 2 Old Street and Ancestral Temple of the past
From [Yaotou memory], Mao, Z.A. and Lee, Y.L. and において、集落の空間構成に影響を 及ぼしたと考えられる(Fig. 2)。

\section{3 堯頭村の歴史的景観の特徵}

上記を踏まえ、堯頭村における代 表的な歴史的景観を整理する。ここ でいう歴史的景観とは、窯業最盛期 の土地利用、町並み、建築物等が継 承され、往時の状況を垣間見れる景 観のことである。なお、本稿では、作陶や流通・販売に関わる歴史 的景観を主とし、宗族ごとの居住区については扱わない。

最盛期の集落の断面を示したのが Fig. 3 であり、後河（現在は消 失）が形成する谷地形に窯元が集積していた。なお、Fig. 3 及び 4 に おける I ， II は対応関係にある。窯業の衰退に伴い、生産エリアの 荒廃が進んだが、窯跡の「全国重点保護単位」指定などを経て、現 在は、遺跡としての保存・整備が進められている。生産エリアの歴 史的景観の特徴として、以下の点を指摘することができる。1）階段 状の地形を利用して建設された窯洞が並んでいる。2）窯元は、敷地 奥側の崖に沿って葖洞が設けられ、前面に平坦な中庭を有する「半 用み」空間であり（Fig. 4）、その下層には、傾斜面を利用した饅頭 窯がある。3）中庭の端には、下層に下りる細い坂道が設けられている。 階段状地形の中間層には道路があり、中間層にある窯元は、通りと 直接面している。4）窯元の工房や倉庫として利用されてきた窯洞注 11) の多くは、窯業の衰退により使われていない。5）窯洞のファサード、 饅頭窨、道路側の垣の建造材料として、集落の至るところで匣鉢（陶 磁器焼成の際に用いる耐火性の容器) や磁器の残片とレンガが用い られている。

集落中央の平坦な高地に東西に広がる老街は、2 層（老街 I ・ II ） の階段状地形に構成され、最盛期には、様々な店舗が立ち並び、と りわけ老街 II では、陶磁器販売で賑わったが、新村への移住や窯業 の衰退を経て、飲食店や日用品店が多く、祠堂などもあった上層（老 街 I ）（Photo2）、及び下層（老街 II ）の店舗共に、廃噓化が進んだ 注 12)。しかし、法制度整備や補助金を伴う町並みの関連事業の進展に 伴い、近年、少しずつではあるが、通りに賑わいが戻ってきた。こ れらの経緯を踏まえ、老街における歴史的景観の特徴として、以下 の点を指摘できる。1）通り沿いには、修復・再建された店舗が立ち 並び、歴史的町並みが形成されている。2）老街 I では、店舗の典型 的な敷地構成として、背部に住居を有する「窯洞＋合院式」の「全 


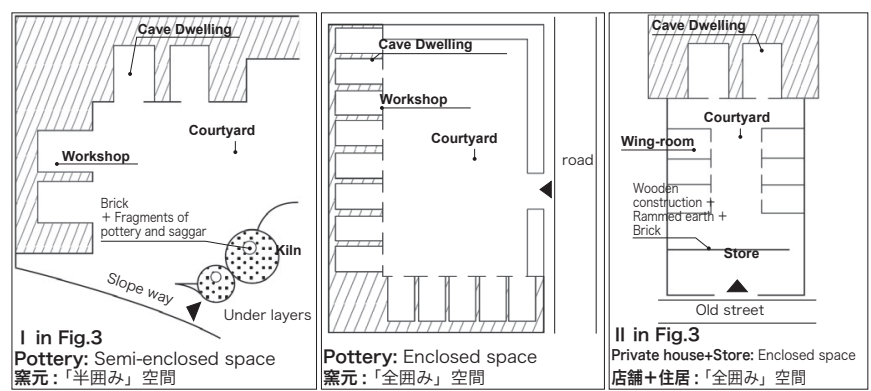

Fig.4 Type of site layout (I and II in fig.4 are compartible with them in fig.3)

囲み」空間が維持されている（Fig. 4)。3）再建された町並みに、飲 食・日用品店 ( 老街 I ) や陶磁器販売店 ( 老街 II ) が一部再生され、 銀行や祠堂などの特異な建築物はランドマークとなっている。

\section{3 堯頭村における窯元の生産環境}

\section{1 窯元再興の経緯}

堯頭村における窨元の再興経緯や生産環境 (空間及び経営面での 特徴）の現状を明らかにするために、2018 年 3 月と 2019 年 2 月に現 地踏查を行い、窯元の位置、作陶工程と空間構成との関係、生産さ れる陶磁器の種類を把握し、ヒアリング調查により、窐元の再興経 緯、経営形態、宗族や行政との関係、生産される陶磁器の特徴 (4 章)、 販売・流通手法 (5 章) 等に関する情報を収集した。

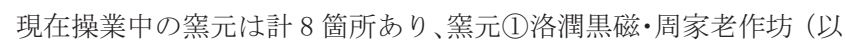

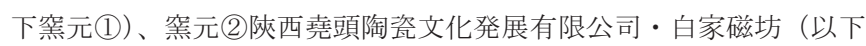

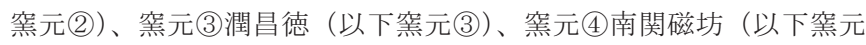

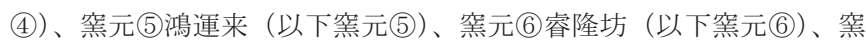
元(7)白氏黒砂（以下窯元(7)）、窯元8)周氏父子（以下窯元(8)）である。 前述のとおり、堯頭村の伝統的窯業において、成形や施橎などの各 作陶工程を行う工房の集積が割元であり、それらが集積して、宗族 ごとの作陶区が形成されてきた（Photo1）。現在でも、一つの窯元は 複数の工房から構成されているが、一部は、かつては宔業以外の用 途にも使われていた施設を転用したものである。

再興経緯について、致元 (1) 1958 年以前から現在に至るまで、 家族によって継承されてきた窯元を継続利用している。その他 7 箇 所の致元は、主に 2013 年以降、文化遺産保護の展開及び行政支援に より再興された。㝙元(2)、堯頭嘿の伝統的技術が「中国無形文化 遺産リス卜」記載後設立され、かつての致神廟跡に建てられた小学 校跡地に開業した（建物を一部転用）。開業に際し、行政から企業向 けの経済的支援を受けた。堯頭窯の観光資源化が進む中で、観光管 理センターや行政、専門学校と連携し、技術研修会や窯神祭をよく 開催している。窯元(3)(4)(5)の経営者は、集落の「伝統的集落」及び「歴 史文化名鎮」への登録を契機に開業した。窯元(3)(5)の敷地は隣接し、 白氏の旧居住区に位置する。窯元(3)は白氏の旧民家を転用し、窯元 (5)は民家の敷地を一旦更地にした後、複数の窯洞を新築した。さらに、 観光開発の影響を受け、2017 年以降に個人型の宰元(6)(7)8が開業し

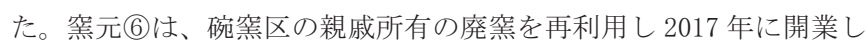

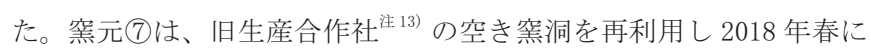
開業し、経営者は中国南部の陶磁器生産地で新たな作陶手法及びデ ザインの調査を経て、2019 年 1 月に開業した。同年窯元8は、合院 様式の周氏旧住宅を転用し開業した。全蔩元の職人は、新村に居住し、 毎日通勤している（Table1）。

\section{2 生産環境の現代化}

\section{2.1 経営面の特徵}

窯元(1)(3)(6)(7)(8)は、集落住民が経営者と職人を兼任する個人型の

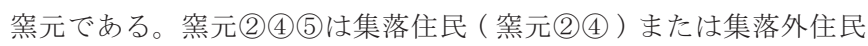
( 䆬元(5) ) が経営を専任し、集落住民を職人として雇用する企業型の 窯元である。職人を含む窯元の総従業員数は、企業型は 20 人以上で あり、担当作業は販売、管理、作陶等明確に分けられ、作陶も工程 別に担当職人がいる。個人型割元には、2 人程の職人がおり、上記の 全工程を 1 人で行う。職人の作陶技術は、個人型の場合、国家、省、 県級レベルの職人が多く、少数ながら弟子もいる注 ${ }^{14)}$ 。企業型の窯元 は、いくつかの嚜元に県級レベルの職人がいるが、認定を受けてい ない職人のみの嚜元もある。窯元(5以外の 7 箇所の窯元は、集落に 居住する李、周、白、宋、劉氏のいずれかが経営している。

経営面の現代化における特徵は 2 点ある。第一に、経営形式につ いて、伝統的な宗族分担作業制度の下で家族経営されていた小規模 工場から、個人型または企業型の窯元への転換があった。宗族分担 作業制度は失われ、各窯元は陶磁器の種類を制限されることなく、 自由に黒磁器や茶碗、喆等の陶磁器の生産が可能となった。第二に、 単独の宗族による経営や子孫への継業の強制がなくなり、集落住民 のみならず、外部者（窯元(5)）が、窯元の経営者や職人となる場合 も見られ始めた。経営者属性が多様化した一方で、集落内の若者の 作陶技術習得の意欲は弱く、人材育成面での課題がある。また、新 規の個人型の羔元に対する起業や経営の支援が欠けている。

\section{2.2 空間的特徵}

空間面での窯元の生産環境の実態を把握するために、各窯元の施 設配置図（Fig. 6) を作成した。いずれの致元も階段状の地形を利用 した窯洞を多様な目的（工房、事務室、展示室）で利用し、敷地全 体は、中国北部の建築的特徴である合院式の空間構成である。

空間面における現代化の特徴として、以下 3 点を指摘できる。第 一に、立地については、かつて水簸などを行っていた後河周辺及び 成形から焼成までを行なっていた宗族ごとの 4 箇所の作陶区は、現 在は遺跡として保護されている。自動車や機械設備（水道、攪拌機、 ロクロ、水簊用の機械等) の導入により、原料地や川など自然資源 から離れた場所でも作業が可能になり、旧村中心部の老街周辺と観 光客向けの集落の入口付近などの旧村のかつての生活エリアを中心 に葖元が再興し、ここには少数ながら、現在も住民が居住している。

第二に、致元の敷地内の空間構成に関して、かつては小規模敷地 内で効率的に作業を行うために、二面が窯洞で、道路側が開けてい る「半囲み」の空間構成 (Fig. 4) であったのに対して、企業型の窯 元(2)(4)(5)の敷地 (Fig. 6) では、敷地規模が拡大し、道路沿いにも施 設を配置した「全囲み」空間へと変化し、敷地の閉鎖性が強くなった。 また、各工程ごとに別の職人が担当するようになり、敷地内の工房 や窯の数も増加している。

第三に、作陶工程と作陶空間との関係についてである。現在、概 补全ての窯元は、原土の乾燥、水箕、土作りを敷地内の中庭、成形 や施釉を致洞様式の工房内で行う。成形後の生地の乾燥には、工房 隣接の倉庫を利用することもある。企業型の窯元は、作陶工程の現 代化に伴い、施設内に機械化した擋拌機やロクロを導入し、水箕用 の沈殿池、ガス㝘や工房などの設備、また事務室や観光客向けの屋内・ 屋外展示室、体験及び飲食スペースも増設した。個人型の致元(1)(3)、 


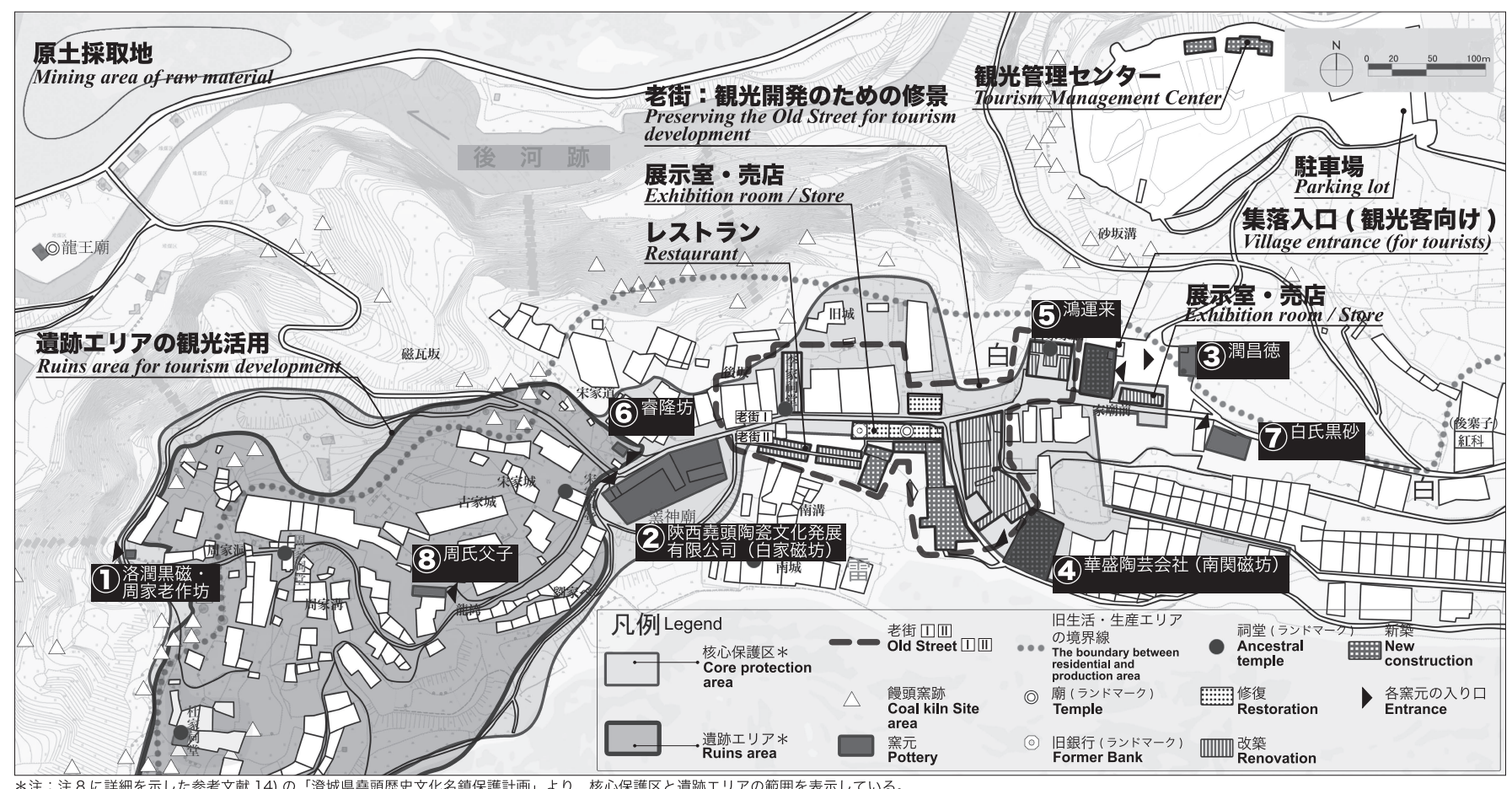

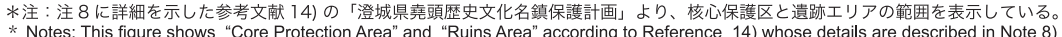

Fig.5 The spatial layout of the current situation of ceramic industry
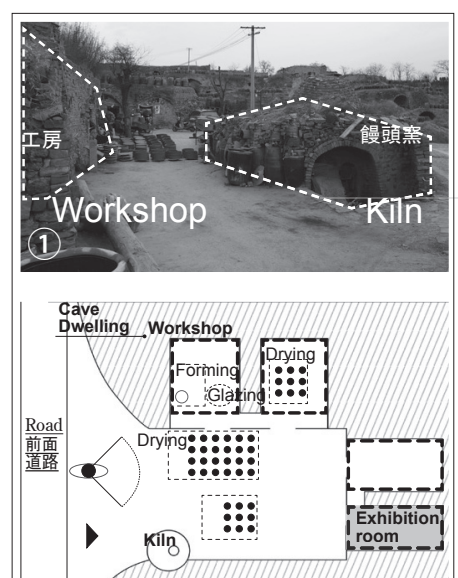

窯元 (1) / 個人経営

Pottery (1) /self-employed

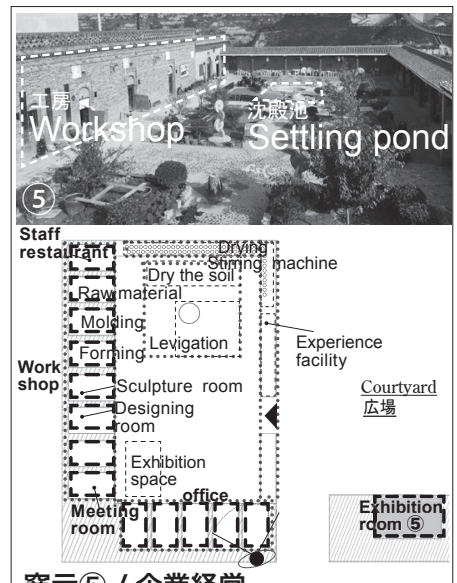

窯元(5) / 企業経営

Pottery (5) /enterprise

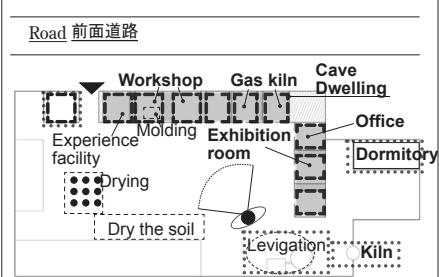

窯元(2) / 企業経営

Pottery (2) /enterprise
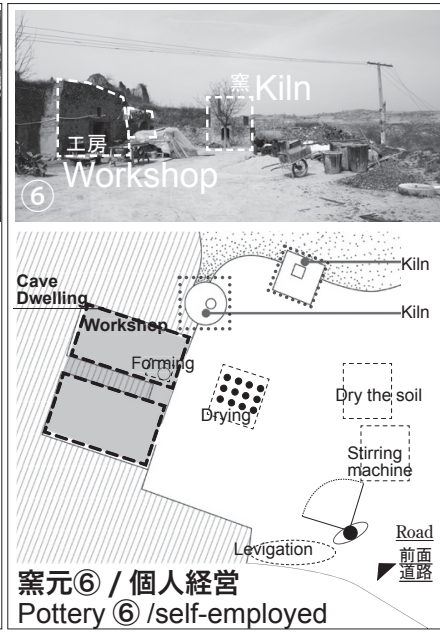

Pottery 7 /self-employed

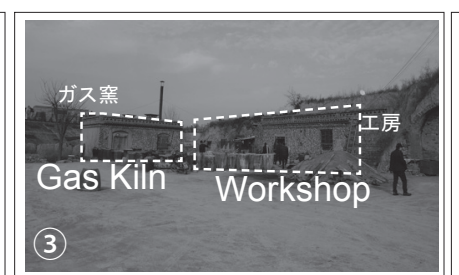

\section{(3)}
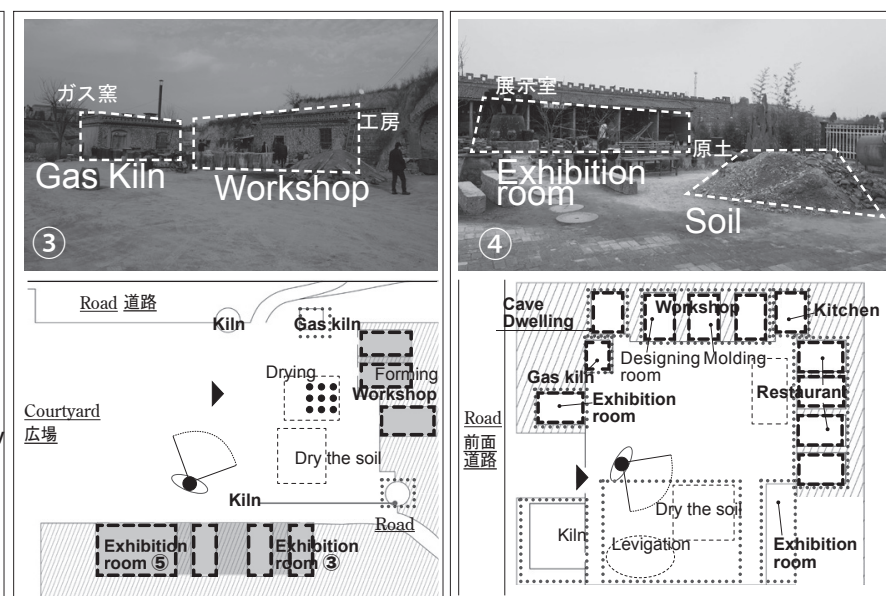

窯元(3) / 個人経営

Pottery (3) /self-employed

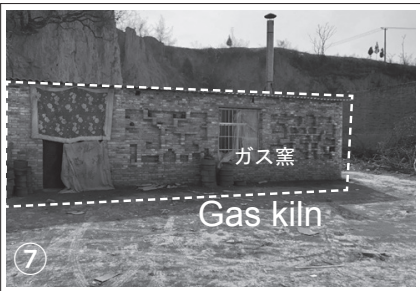

Road前面道路

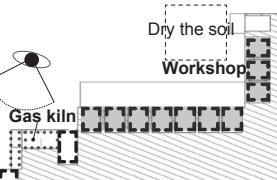

\section{[TITILI}

窟元7 / 個人経営

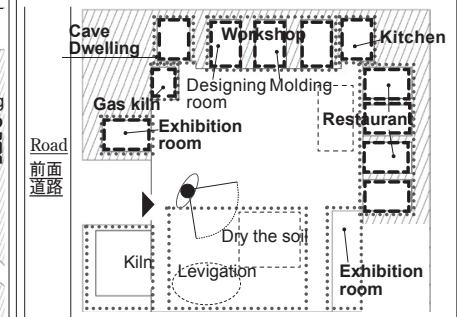

窯元(4) / 企業経営

Pottery (4) /enterprise

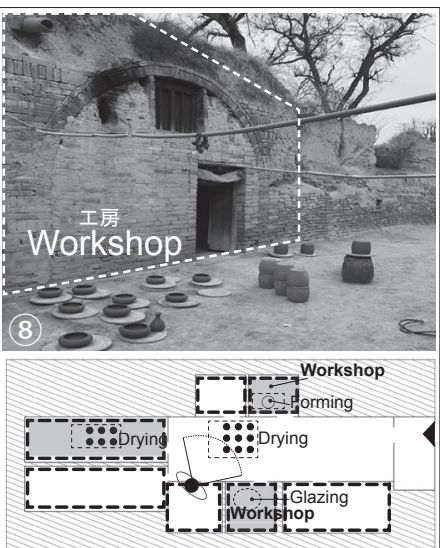

窯元8 / 個人経営

Pottery (8)/self-employed

Fig.6 The layout of the pottery sites 
Table 1 The present situation of each pottery's production environment

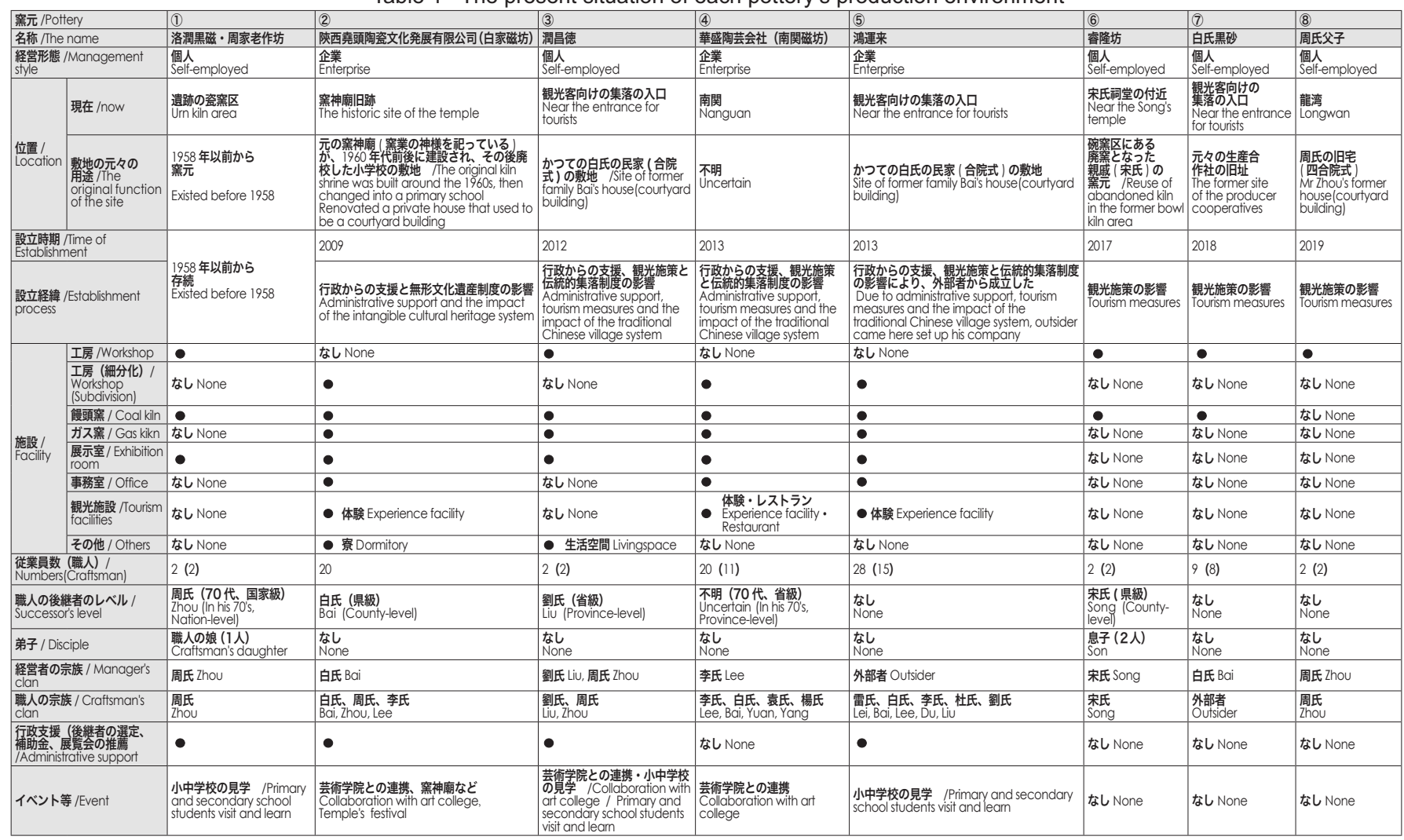

致洞形式の展示室を増設している (Fig. 5, Table1)。

\section{3 窯元の生産環境の現代化による歴史的景観への影響}

生産環境の現代化について、まず、経営形態は個人型と企業型に 分けられ、後者は比較的従業員数が多く、作陶工程の分担化、機械 設備の導入等が顕著であり、また、観光地化の影響により、窯洞が 展示室等の新たな機能を持つようになった。このような生産環境の 現代化において、1）地形を利用した空洞や饅頭窵については、その 継承が随所に見られる。2）窯元の敷地構成については、個人・企業 型に関わらず合院式の平面構成や中国北部特有の窯洞が継承されて いる一方で、特に企業型の敷地規模は拡大し、「全囲み」空間が一般 的になりつつある。3）利便性を勘案し、最盛期のような階段状地形 の中間層に立地する窯元は減少し、主要道路に隣接する致元が大半 を占める。4）再興した致元には、旧生活エリアに点在する旧民家や 旧敜神廟、廃窒となっていた建物の一部を活用、または展示室に転 用寸る例が見られる。5）伝統的な建築材料を用いて饅頭窯や作陶以 外の機能 (展示室、事務室、レストラン等) を担う致洞の新築が見 られた。一方、中庭ではコンクリート製の構造物の設置がされるなど、 敷地内の構成要素の変化もみられる。

\section{4 堯頭村における製品の特徵と作陶手法}

\section{1 陶磁器の種類・デザイン}

堯頭村の窯業は古来より堯頭窯と呼ばれ、多くの窯元は、日用品 として使われる製品を生産していた。堯頭村で生産される陶磁器の 形状や意匠は今でも粗野で古めかしく、磁器については、中国の陶 磁器の分類では、「粗磁」に属する。原土と釉薬の原料は、堯頭村で 採掘され、前者がカオリン石、後者は酸化鉄を含有する鉱石である。 酸化鉄を含む黒色の釉薬の作用により、堯頭村の代表的な磁器は黒
磁器である。磁器以外には、陶器に分類される砂器が少量生産され、 伝統的な砂器は、白氏宗族のみが生産していたが、現在は新設の窒 元(7)において、現代的デザインの砂器が生産されている。

致元と展示室へのヒアリング調查及び堯頭村の伝統的な陶磁器に ついての言及がある文献資料 ${ }^{15)}$ から、各宰元で生産されている陶磁 器の種類とその販売数割合を作成した (Table2)。一般的に、壶や面盆、 民用の老碗、筆立て等の文房具、香炉等の磁器と、少量ではあるが 砂鍋を生産している。これらは、古来より継承されてきた伝統的な 種類・デザインの陶磁器である。その他湯飲みや急須などの日用品、 瓶、置物などの工芸品、記念の皿等、現代の暮らしに合うような種類・ デザインの陶磁器も生産している (Photo3)。

概ね全ての窯元において、伝統的な種類・デザインよりも、現代 的種類・デザインの磁器の販売割合の方が高いが、企業型の㷱元 (4)(5)、両方を同程度販売している。窯元 (1) (2) (6) は、生活用品や 工芸品等の現代的な種類・デザインの磁器を大量に生産している。 2018 年新設の窯元(7)は、多様な現代的種類・デザインの砂器及び少 量の磁器を生産する。窯元(3は、デザインごとの明確な販売割合の 情報は得られなかったが、伝統的・現代的種類・デザインの磁器の 両方を生産していることが判明した。

\section{2 伝統的作陶手法と現代的作陶手法}

堯頭村の致業に関する文献資料 ${ }^{9,13,14)}$ と現地調查に基づき、現在の 窯元における作陶手法は、伝統的 / 現代的作陶手法に分けられると 考えた。具体的には、磁器の伝統的作陶手法は、原土の採取から焼 成までの全工程を、職人 122 人で行う。基本的には、石炭を燃料に、 饅頭窯で、4 日間ほど高温焼成 $\left(1200^{\sim} 1280\right.$ 度) し、その後、3 日間 自然冷却をする。高温焼成により、酸化鉄を主成分とする釉薬に窯 変が起こりやすく、仕上がりの質や芸術的価值が高い。 
Table 2 Sales proportion of pottery's porcelains and target customers

\begin{tabular}{|c|c|c|c|c|c|c|c|c|c|c|c|}
\hline \multirow{3}{*}{ 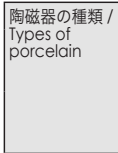 } & \multicolumn{5}{|c|}{ 伝統的な種類・デザインの陶磁器 /Traditional types and design } & \multicolumn{5}{|c|}{ 現代的な種類・デザインの陶磁器 /Modern types and design } & \multirow{3}{*}{$\begin{array}{l}\text { zの他 } \\
\text { Others }\end{array}$} \\
\hline & \multicolumn{3}{|c|}{ 生活用品 /Life supply } & \multirow{2}{*}{\begin{tabular}{|l|} 
文房具 /Stationery \\
筆立 $/$ / 筆洗 \\
/Wrus pot \\
/Writing-brush washer
\end{tabular}} & \multirow{2}{*}{\begin{tabular}{|l}
$\begin{array}{l}\text { 祭祀の用品 / } \\
\text { Worship } \\
\text { supply }\end{array}$ \\
香炉 / \\
Censer
\end{tabular}} & \multicolumn{2}{|c|}{ 生活用品 /Life supply } & \multicolumn{3}{|c|}{ 工芸品 /art craft } & \\
\hline & 斝/Pot & \begin{tabular}{|l|} 
面盆 / \\
Wash basin
\end{tabular} & $\begin{array}{l}\text { 老䃄 / } \\
\text { Old bowl }\end{array}$ & & & $\begin{array}{l}\text { 湯のみと急須のセット / } \\
\text { Teacup and teapot }\end{array}$ & \begin{tabular}{|l|} 
湯のみ \\
Teacup
\end{tabular} & $\begin{array}{l}\text { 瓶 / } \\
\text { Bottle }\end{array}$ & \begin{tabular}{|l|} 
置物 / \\
Decoration
\end{tabular} & $\begin{array}{l}\text { 記念の血 / } \\
\text { Commemorative } \\
\text { Plate }\end{array}$ & \\
\hline 案元(1)周·個 & . $(10 \%)$ & (集)（観） & 。(10\%)（観） & & & ○(60\%) (県) (外)（観） & & $\circ(10 \%)$ & 6)（観）(外） & & $\circ(10 \%)$ \\
\hline 案元(2)白·企 & $\circ(10 \%)$ & (集) & 。(5\%)(県) & O (5\%) (県) (観)（外) & & $\circ(30 \%)$ (県) (観) & & 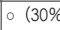 & 6)（観）(外） & & $\circ(20 \%)$ \\
\hline 窯元(3)劉·個 & 。(集)(5 & & $\circ$ o(外) & & & 。(旧) (新) (県) (観) (外) & ○(観)(外) & 。(観) & (外) & & \\
\hline 牢元4)李·企 & $\circ(20 \%)$ & (集) (観)(外) & & o(20\%) (県) (観) (外) & 。(旧) & 。(30\%)(外)（観） & & $\circ(15 \%)$ & 6)（観）(外） & 。(15\%) (県) (外) & \\
\hline 搳元(5)外·企 & $\circ(7 \%)$ & 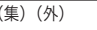 & 。(14\%)（集） & o(21\%) (県) (観) (外) & & $\circ$ o(36\%) (県) (外) (観) & & 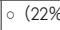 & 6)（観）(外） & & \\
\hline 窯元(6)宋·個 & $\circ(10 \%)$ & （集）(観） & $\circ(5 \%)$ (観) & 。(20\%) (観)（外） & & $\circ$ (40\%) (県) (外)（観） & & 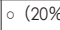 & 6)（観）(外） & & $\circ(5 \%)$ \\
\hline 寗元(7)白 $\cdot$ 個 & & & & & & $\circ(80 \%)$ (観) & & $\circ(20 \%$ & 6)（観） & & \\
\hline
\end{tabular}

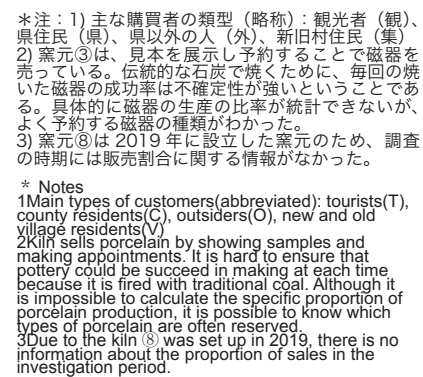

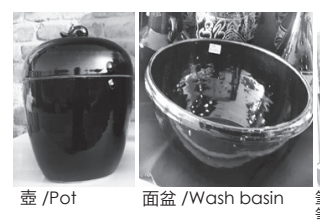

Photo 3 Types of porcelain

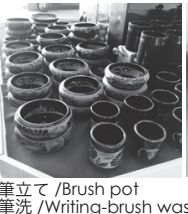

筆流 $\tau$

これに対して磁器の現代的作陶手法においては、基本的な工程は 変わらないが、各工程（成形、装飾、施釉等）を担当する専門の職 人がいる。基本的には、石膏の型で成形し、乾燥、装飾、施釉をし てから、ガス窐を利用して、1000 度程度で 3 日間程度焼成する。伝 統的作陶手法と比較寸ると、設備の機械化や分担制により作業時間 が大幅に削減され、大量生産も可能である。そのため、種類やデザ インが豊富であり、かつ低価格で市場に流通可能である。ただし、 伝統的作陶手法で生産された磁器と比較すると、低温で焼成される ために效変が起こりづらく、芸術的価值が高いとは言えない。

他方、砂器の伝統的作陶手法は、磁器とは異なり、成形した砂器 を、棒状の道具を使いながら一つずつ小さな窐の中に入れ、1200度 程度の高温で夜間に 3 分間焼成するが、現在この手法はあまり使わ れていない。現代的手法は、成形した砂器を一度にガス窯の中に置 き、 4 度/分の速度で 1250 度程度まで加熱し、その温度を 80 分間保 ち、自然冷却して筤から出すというものである。現代的作陶手法では、 大量生産が可能で高品質であるが、伝統を継承していないと言える。

\section{3 作陶手法及び製品の種類・デザインの現代化からみた窯元の類} 型化

上記の陶磁器の種類・デザイン (4.1) と作陶手法 (4.2) に関して、 伝統的か現代的かという視点から、8 箇所の致元を 4 つに類型化し、 各類型の特徵を考察する (Fig. 7)。

タイプ i ：伝統的作陶手法により、伝統的および現代的な種類・ デザインの磁器の両方を生産する窐元であり、窯元(3)が該当する。 このタイプは、原土採取から饅頭穼での焼成までを一人の職人が行 う。また、伝統的磁器に加え、伝統的デザインを取り入れた現代的 デザインの磁器も生産している。職人は、省級無形文化遺産後継者 であり、生産技術及び装飾技術のレベルが高い。よって、タイプi の葖元により作陶された磁器は、文化的価值と芸術的価値ともに高 く、器の愛好家や専門家、磁器の作家、集落住民の中で知名度が高い。

タイプ ii ：現代的作陶手法により、主に現代的なデザインの磁器 を生産し、伝統的デザインの磁器も少数生産する窯元であり、致元 (4)(5)が該当する。企業型の㪇元であり、敷地規模が大きく、各作陶 工程ごとに工房が設置され、経営者は新村住民である。現代的作陶 手法を用いるため、低コストで、伝統的・現代的種類・デザインの 磁器の両方を大量に生産することができ、市場での流通量を保持で

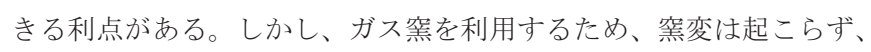
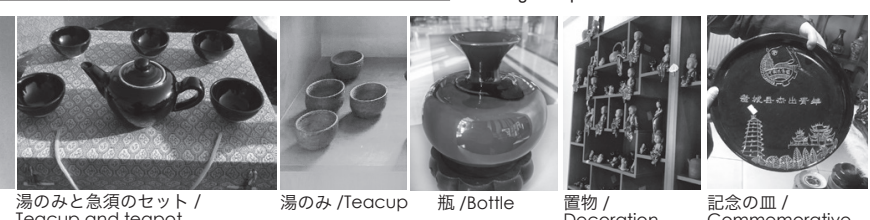

置物 /
Decoration 記念のm
Comme
plate

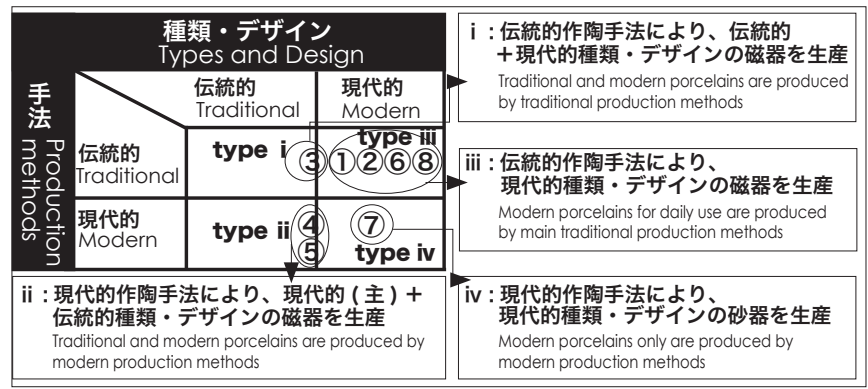

Fig.7 Four types of eight potteries from the viewpoint of production method and design

仕上がりの質や芸術的価值が高いとは言えない。

タイプ iii ：伝統的作陶手法により、主に現代的種類・デザインの の磁器、とりわけ生活用品を生産する窯元であり、嚜元(1)(2)(6)(8)が 該当する。窯元(2)を除いて個人型割元であり、その中で窨元 (6) (8)は 伝統的集落における無形文化遺産の再評価と観光開発のう㸚りの中 で設立された。このタイプの窯元で生産される磁器は、文化的・芸 術的価值は低いものの、大量生産ができないために販売価格が高い。

タイプiv：現代的作陶手法により、現代的種類・デザインの砂器 のみを生産する窯元であり、窯元(7)が該当する。砂器は、かつては 白氏が生産を担当し、現在は、土産や贈答目的の湯のみや急須及び 置物等の現代的な工芸品が生産されている。なお、宰元(7)は元々四 川省での作陶経験がある職人を雇用している。

\section{4 作陶手法と製品の現代化による歴史的景観への影響}

製品の現代化については、原土、黒磁器の釉薬素材及び、デザイ ンを継承しながら、現代の生活スタイルに合わせた種類の陶磁器や 鑑賞性の高い陶磁器の生産が行われている。宗族分担制度消失以降 も基本的な作陶工程は変わらない一方で、工程ごとに別の職人が担 当し、また機械設備やガス致の導入が行われてきた。

以上のような作陶手法及び製品の現代化に伴い、生産エリアの歴 史的景観に対して、以下の 3 点の影響を及ぼしていると考えられる。 1）水箥や土づくりなどの工程において、自然資源への距離的な依存 度が小さくなり、作陶関連の景観は致元内に集中寸るようになった。 2) 各工程に一つの工房が必要になり、それに伴って、かつての別用 途の晏洞を工房として転用寸るようになった。また、伝統的作陶手 法を用いる窯元では、饅頭窯が継承され、嚜から煙が立ちのぼる景 観も継承されている。3）歴史的景観に調和した嚜洞や镘頭窯が新築 されている一方で、コンクリート造の水簯設備やガス窸など、歴史 


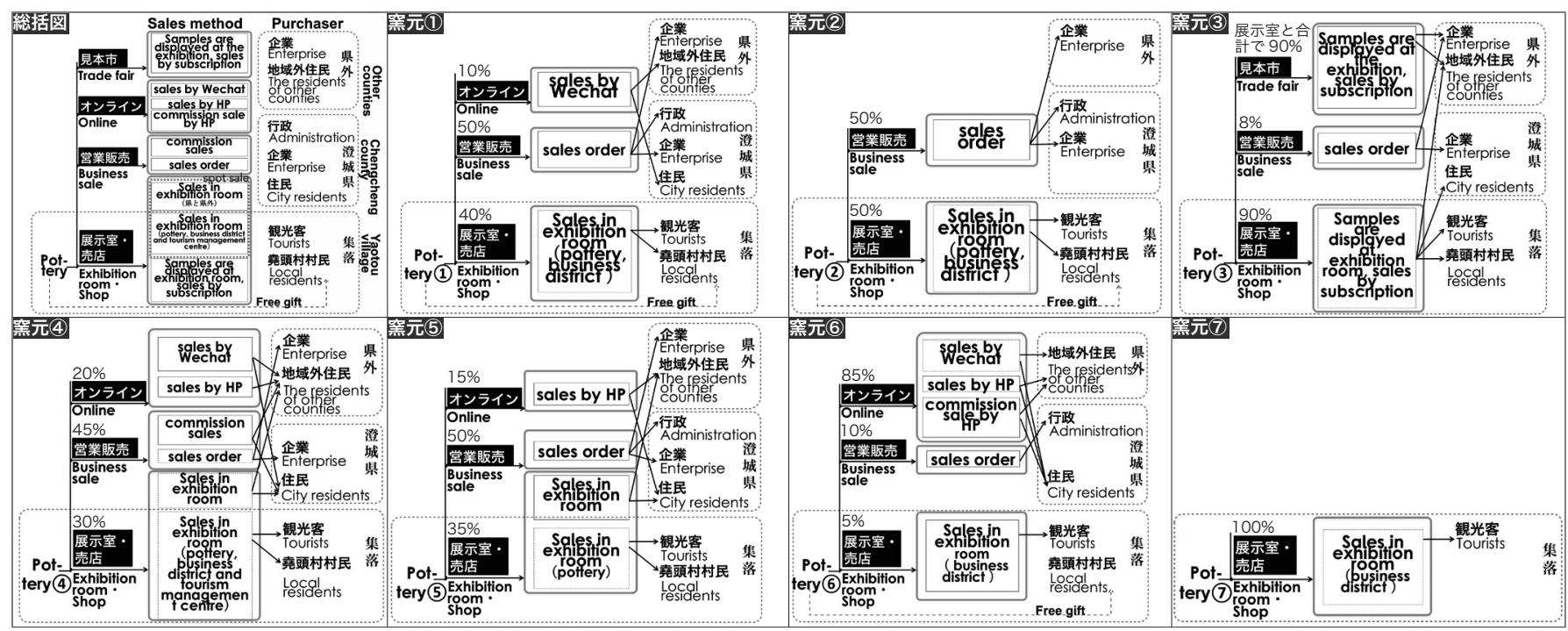

Fig. 8 The present situations of distributions and sales methods of each pottery of Yaotou village

的景観と調和しない施設も付加されている。

\section{5 堯頭村における陶磁器の流通・販売手法}

\section{1 流通・販売手法の実態}

窯元や展示室への調查により陶磁器の流通・販売手法を把握し、 総括図及び各致元の現状図を作成した（Fig. 8)。流通・販売手法は、 以下の 4 通りに分けられる。

1) 見本市での予約販売 : 政府や行政が関与する大規模な見本市や博 覧会において、製品の見本を展示し予約販売する手法。基本的には、 選出された窯元のみが出展できる。

2) オンライン (Wechat、ホームページ) での販売。

3）企業や行政向けの営業販売：政府や企業による賞や贈答品、ホテ ルによるインテリアや食事提供用の陶磁器など、企業や組織を顧客 として大口注文を請け負う手法。

4) 展示室・売店での販売 : (1) 直売 : 窯元併設店舗、老街、観光管理 センター、地域外にある展示室や売店で、直接販売する方法。 (2) 予約販売 : 窯元併設の売店、老街にある展示室・売店において、見 本を展示し、注文を受けてから職人が作陶する方法。

\section{2 窯元タイプごとの流通・販売の現代化の特徵}

上記の流通・販売手法は、窯元の作陶手法や陶磁器の種類・デザ インと何らかの関係があると考え、前章の窯元類型に基づき考察を 行う。

まず、タイプ i (窨元(3)）によって生産される磁器は、その芸術 的価值が広く認められ、窐元併設及び老街の展示室での販売に加え て、政府や行政から支援を受け、地域外の展示や見本市に出展寸る 機会が多く、直売や予約販売が多いと考えられる。また、少数では あるが、県と地域外の企業からの受注販売も請け負っている。

タイプ ii (窯元(4)(5)）は、現在、窯元併設の展示室や観光管理セ ンターに加えて、地域外にも自営の展示室・売店を設置している。 また、窯元の敷地が広く中庭での展示・販売が可能であり、さらに、 飲食・宿泊施設も併設され、地元の高校生や観光客を対象に作陶体 験などの普及活動も行っている。これらの施設や活動は、堯頭村の 㷯業及びその知識や歴史を、地域内外の人に広く普及するのにも有 効な手段である。集落内の展示室や売店では、特に祝日や大型連休
中の観光客による土産品の購入が多く、時期や季節による偏りが大 きい。また、割合は少ないが、集落の住民向けに贈答用の湯のみや 急須などの販売も行なっている。このタイプの窯元は、現代的手法 により現代の需要に合わせた現代的種類・デザインの磁器を中心に 生産し、上記に挙げた手法の他、県や地域外の企業からの受注販売、 オンライン販売を含む多様な販売・流通手法を用いている。

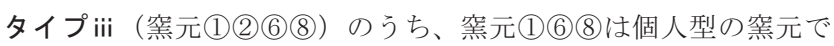
あり敷地が狭く、このうち窯元(6)8は、敷地に展示室を設置してい ない。また、出稼ぎの経験などから、地域外の人脈が豊富である。 これらの理由から、割元(1)(6)では、Wechat (無料インスタントメッセ ンジャーアプリ）などを使ったオンライン上での販売を積極的に用 いる。窯元 81、新設直後に調查を実施したため、当時は販売が始 まっていなかったが、将来的にオンライン販売をする可能性は高い。 オンライン販売の場合、作陶の進渉状況や磁器の情報の発信が容易 かつ、購入も気軽にできる。また、費やした時間や品質などに応じ て、致元側が比較的自由に価格を設定できる点が優れている。しかし、 地域外の人が集落を訪れないために、実際の生産環境や工程及び集 落景観や土地固有の文化を知り、深く理解することが難しい。一方で、 窯元 (1) (2) (6) は、展示室で観光客向けの販売も行う。特に、致元(1)に 併設の展示室では、伝統的な作陶設備や作陶工程が紹介され、ガイ ド付の観光客がよく訪れる。また、窯元(2)は、企業や行政向けの大 口の営業販売も行っている。その他の特徴として、窯元(1)(2)(6) 住民に対して、無償で不良品の磁器を提供する。伝統を継承しつつ、 現代的な磁器を生産するこのタイプについては、窯元の個性が強く、 その特徴を総合的に述べることは難しいが、オンライン販売と観光 客向け販売の積極利用は、その特徴の一つである。

タイプiv（窯元(7)）は、調査当時は、老街の展示室のみで砂器を 販売していたが、経営者の年齢は若く、窯元 (6) 職人と同様、集落 外での出稼ぎにより形成した豊富な人脈を生かし、今後はオンライ ン販売を利用する可能性があると推測できる。

以上の考察を踏まえ、堯頭村における陶磁器の流通・販売の現代 化の全体的な傾向を以下のように整理できる。1）若い職人・経営者 を中心に、オンライン販売が普及し始めており、また、この手法を 利用するいくつかの窯元は個人経営で敷地が狭く、敷地内に展示室 
Table 3 Influence of modernization of ceramic industry on historical landscape of Yaotou village

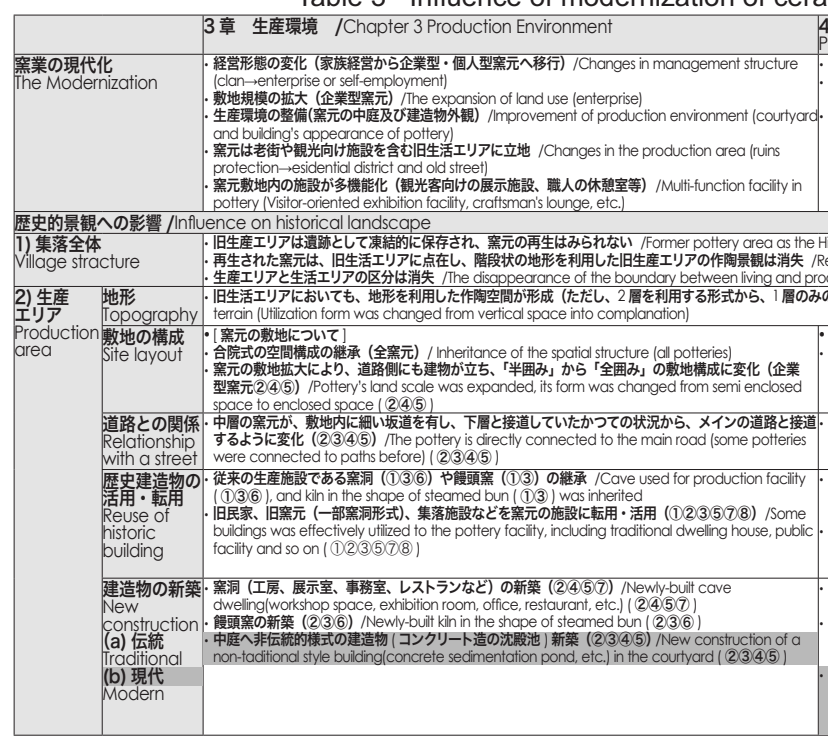

を併設することが難しい。2）現代的な経営形態である企業型の垁元 の購買者属性は、企業や行政を顧客とする大口の営業販売から、観 光客まで幅広い。3) 陶磁器の芸術性と職人の技術レベル（国家や省 からの認定) が高ければ、見本市などへの出展機会を多く与えられる。 4）集落の観光地化が進み、全窯元が、観光客に対して、一定程度陶 磁器を販売している。

\section{3 流通・販売の現代化による集落の歴史的景観への影響}

流通・販売の現代化に伴い、窯元が販売・展示のための施設を増 設する際に、生産エリアでは、伝統的様式の窯洞を増築する、廃屋 化していた旧小学校・旧民家などの嚜洞を修復する、などの歴史的 景観の保全に貢献する行為がみられる一方で、中庭に非伝統的様式 の簡易な展示スペースを設けるといった事例もみられる。

他方、老街では、歴史遺産保護や観光開発の進展により、通り沿 いの店舗建築の修復や、銀行や宗族の祠堂、廟などのランドマーク に関してもかつての空間構成及び建築材料を用いた復元整備が進み、 これらは䈇元展示室・売店としての機能も持ち、陶磁器の販売・流 通が盛んに行われた往時を想起させるものである（Photo4）。

\section{6 結論}

本稿では、かつての陶磁器の一大生産地中国陝西省堯頭村を対象 に、再興しつつある伝統的窯業の生産環境 (3 章)、作陶手法や陶磁 器の種類・デザイン (4 章)、販売・流通手法 (5 章) の現代化につい て調査し、経営形態の変化、生産・販売環境の整備、製品 (陶磁器) の多様化、また、販売手法及びターゲットの多様化の経緯や要因、 詳細な実態を明らかにした。その上で、このような窯業の現代化に よる歴史的景観への影響を考察した。本研究の結びとして、集落全体、 町並夕、敷地という3つの空間スケールを設定し、それぞれに対す る窯業の現代化の影響を考究する(Table3)。

第一に、集落全体の空間構成として、窯元は老街や観光拠点周辺 に偏って再興している。これは、窯業の自然環境への依存度の低下、 観光客のアクセスなどが影響している。遺跡として凍結的な保存が 進められる旧生産エリアや、住民の新村移住で空洞化の著しい旧生 活エリアを有する堯頭村において、現代化された窯業の再興は、よ りいっそう老街や観光拠点の強化を促してゆくものと考えられる。

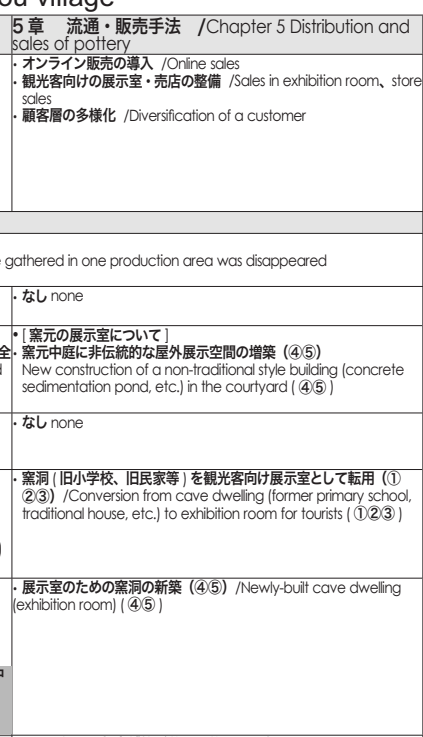

第二に、町並みス ケールとして、面的に 広がりを持って再生さ れているのは、歴史遺 産保護（リストへの記 載や修復への補助制 度）や観光開発のため に整備された商業集積 地の老街である。2 層 で構成された老街で は、最盛期と同様、通 りの両側に店が並び、 上層（老街 I ）の復元

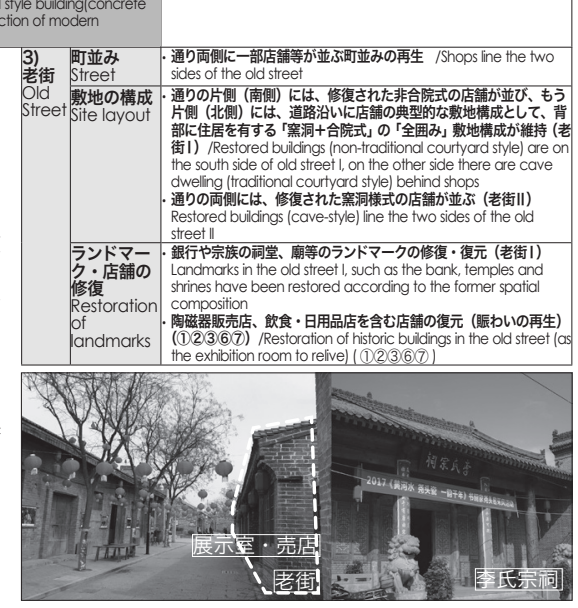

Photo 4 The current Old Street and Lee Clan's ancestral temple (2018)

された店舗は、主に観光客向けの窯元の展示室・売店として活用さ れている。また下層(老街II)でも、飲食店等への転用等もみられ、人々 で賑わう景観が形成されている。一方、前述のとおり、老街以外の 旧生産・生活エリアへの宰元再興の影響は限定的であり、現状では 生活や生業を伴う面的な町並みの再生には至っていない。

第三に、敷地スケールでは、再興後の窯元の多くは、従来と同様 に地形を利用した窒洞や僈頭黡及び合院式の空間構成が継承されて いる。また、多機能化に対応し、廃屋化していた建造物の活用・転用、 従来の伝統的な建築材料・構法により饅頭窸や窯洞の新築がみられ た。その一方で、特に規模の大きな企業型の窯元では、増築による 敷地構成の変化 (半囲みから全囲みへ) や、中庭での動力機械を用 いた水簸や原土乾燥作業が、敷地の作陶風景を変容させている。

最後に、饅頭窯での焼成時に立ち上る煙や、販売・流通によって 人々で賑わう老街の町並みの景観は、堯頭村の歴史的景観を文化的 景観の観点で評価する際に重要な要素であり、㝨業の現代化が進む 中でも、これらは地域固有の景観として、保全する必要性が高いと 考えられる。加えて、伝統的嘿業には、地域の民俗・風習や地域コミュ ニティの存在も重要な要素であり、現在の生活エリアである新村住 民の参画も重要な論点である。既存の保護計画には、こうした視点 は欠けており、今後、現状把握のための調査研究が必要である。 


\section{謝辞}

本研究は、2018 年度「富士ゼロックス株式会社小林基金」の助成 を得て調查を実施したものである。

注

注 1) 2012 年 9 月 25 日、中国住建部、文化部、国家文物局、財政部の 4 つの機 関部門により、「関於加強伝統的集落保護発展工作的指導意見」が策定され、 伝統的集落に関する定義が具体的に記載された。

注 2）「歷史文化名鎮名村」は、2003 年に中国建設部と国家文物局が制定した 文化財保護制度であり、文化遺産が豊富で歴史的価值を有する地域、また過 去の伝統風情と地方民族の特色ある地域を対象とする。「中国伝統村落」は、 2012 年、中国住建部、文化部、国家文物局、財政部の 4 部局による、伝統 的集落を保護対象と寸る制度である。本研究の対象である堯頭村に限らず、 両者の保護措置や保護・整備内容は同一または類似の場合が多いが、審查基 準においては、後者の方が、歴史的建築物に限らず、地域の歴史、無形文化 など、より幅広い点で地域を審査・評価する。ただ、制度が施行されてから 20 年弱経過していることもあり、条例などの制度も整備され、その効力に ついては、前者の方が強い。

注 3) 2019 年 6 月に中国国家国務院が策定した農村地域の産業振興のための指 導方針である。

注 4) 中国の陶磁器の分類によると、砂器は、陶器の一種である。

注 5）窵洞は中国の陝西省関中地方の北部によくみられる建築様式である。一 般的には、山の斜面や崖に穴を掘る靠崖式と平坦な地面を竪穴の様に鉛直方 向に穴を掘る下沈式に分けられ、堯頭村では、靠崖式が一般的である。

注 6) 現在の堯頭村は、22 ヶ所の自然村と 15 ヶ所の村民小組を含め、新村と旧 村に分けられているが、1975 年以前の旧村は、鎮の行政の中心地である老 街（商業地区）を中心とし、周辺に各宗族の自然村が広がっていた。その 後、1975 年前後に、旧村の東側にある平坦な高地一と、行政の中心が移動し、 新村が開発され、いくつかの自然村は、新村に移転した。

注 7) 全国重点文物保護単位は、中国の文化遺産保護制度の一つであり、遺跡・ 石窟寺院・歴史的建造物などの領域全体を 1 単位として指定している。

注 8）参考文献 14）により、堯頭鎮の保護計画では、(1)東側の白家家廟から西 側の西坂村までの範囲を、「核心保護区」(19.5ha) に指定しており、その中 には、老街を含む生活エリア、現在は遺跡として保護されている生産エリア が含まれており、本研究の調查範囲である。(2)「核心保護区」の外縁 $200 \mathrm{~m}$ の範囲は、「建設制限区」とし、これには、原土採取地及び氷筫の場所が含 まれる。(3)集落全体は「環境調和区」である。以下に、「核心保護区」「建設 制限区」の具体的な保護措置と保護・整備内容を整理する。

\begin{tabular}{|c|c|c|}
\hline & 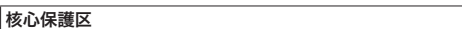 & 建設制限区 \\
\hline $\begin{array}{l}\text { 保護 } \\
\text { 措具 }\end{array}$ & 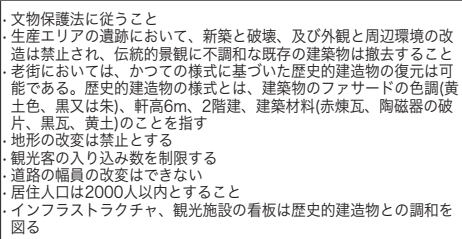 & 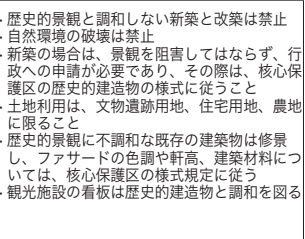 \\
\hline $\begin{array}{l}\text { 保護・ } \\
\text { 内整 }\end{array}$ & 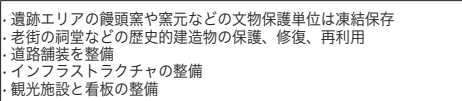 & 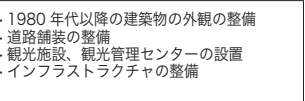 \\
\hline
\end{tabular}

注 9）饅頭窐は中国の北方地区でよく使われる丸型窟である。

注 10) Fig. 2 の生産・生活エリアの境界線は、参考文献 9) 14）上り、各作陶区 の区分は、高齢の村民と管理センターへのヒアリング結果から示した。

注 11）堯頭村における空洞は、住居、作陶、商業など、多用途に利用される。

注 12）参考文献 9）13）及び村民へヒアリングした結果により、かつての老街 における陶磁器の販売・流通の様子及び店舖の概要を把握した。

注 13）生産合作社は、中国農村地区において、農民あるいは住民が連合して組 織した経済組織である。堯頭村では、1975 年以降、行政機構と公共施設が 新村へ移転したため、旧村にある合作社の用地と筸洞が廃止されたが、近年、 案元(7)に再利用された。

注 14）中国の「無形文化遺産」は日本の「無形文化財」に相当し、登録される 伝承者（後継者）の区別は、国家級＞省級＞県級という構造である。

\section{参考文献}

1) Zhou, J.M.: Preservation and Development of Chinese Traditional Village, China Building Industry Press, 2014 (in Chinese)

周建明 : 中国伝統的村落一保護と発展, 中国建築工業出版社, 2014

2) China State Council: Guidance on promoting the revitalization of rural industries, http://www.gov.cn/zhengce/content/2019-06/28/content_5404170.htm, (access 2019.12.1)

中国国務院 : 関与促進哌村産業振興的指導意見, 2019.6

3) Haneda, A.: Changes in pottery and potters (writers), modernization of traditional crafts, Ochanomizu Shobo, 2003 (in Japanese)

羽田新 : 焼き物の変化と窯元・作家一伝統工芸の現代化, 御茶の水書房, 2003

4) Hayase, D.: A Study on "Tradition" in "Crafts", University Art Education Society of Japan, Studies in Art Education, No. 49, pp. 321-328, 2017 (in Japanese) 隼瀬大輔 :「工芸」における「伝統」に関する一考察」, 大学美術教育学会, 美術教育学研究, 第 49 号, pp. 321-328, 2017

5) Fang, L.L.: Yingdezheng in China: the Rising and Development of Private Ceramics Industry, Civilization 21, No.17, pp. 91-105 , 2006. 12(in Japanese) 方李莉 : 中国景徳鎮新時代における民窯の再生とその実態, 文明 21 , No. 17 , pp. 91-105, 2006. 12

6) Yamaguchi, T. and Matsumoto, S. and Nishiyama, N.: A Study on Sustain of Traditional Industry and Cultural Landscape in The Villege of Onta Pottert (Sarayama), Journal of Architecture and Planning (Transactions of AIJ), Vol. 74, No. 644, pp. 2215-2222, 2009. 10 (in Japanese)

山口知恵, 松本将一郎, 西山徳明 : 小鹿田焼の里皿山における伝統的な生 業の持続と文化的景観の保全に関する研究, 日本建築学会計画系論文集, 第 74 巻, 第 644 号, pp. 2215-2222, 2009. 10

7) Maruya, K. and Yamashita, S. and Uchiyama, T. and Ogawa, Y.: Transformation of Pottery-Relevant Cultural Landscape in the Village of Koishiwara, Journal of the City Planning Institute of Japan, Vol. 49, No. 1, pp. 83-92, 2014. 4 (in Japanese)

丸谷耕太, 山下三平, 内山忠, 小川勇樹：小石原焼の里における作陶に関 わる文化的景観の変容に関する研究, 日本都市計画学会, 都市計画論文 集, Vol. 49, No. 1, pp. 83-92, 2014.4

8) Todoroki, S. and Mori, C.: A Study on Space Composition of Pottery and Utilization of Spatial Resources in Shigaeaki, Journal of the City Planning Institute of Japan, Vol. 48, No. 3, pp. 387-392, 2013. 10 (in Japanese) 轟慎一, 盛千嘉 : 信楽町長野における窯元の敷地空間構成と空間資源の 活用, 日本都市計画学会, 都市計画論文集, Vol. 48, No. 3, pp. 387-392, 2013. 10

9) Teng, T.: YaoTou Kiln Space Environment Research in the Perspective of Regionalism, Master Thesis of Xi' an University of Architecture and Technology, 2016. 6 (in Chinese)

10) Wang, X.: The research of protection and development of Yaotou village in Chengcheng county Shaanxi Province based on the concept of Eco-museum, Master Thesis of Xi' an University of Architecture and Technology, 2016. 6 (in Chinese)

11) Wang, H.H.: Study on the Conservation of the KiIn Stove Site in Aneient Times Take three kiln stove sites in Hunan, Jiangxi and Shaanxi as the example, Master Thesis of Xi' an University of Architecture and Technology, 2007. 6 (in Chinese)

12) Wu, R.: Comparative Study on the Characteristics of the Folk Pottery Art in Shaanxi, Master Thesis of Xi' an University of Architecture and Technology, 2009. 6 (in Chinese)

13) Li, D. and Liu, B.D. and Lei, J.S.: The Old town of Yaotou, 2015. 8 (in Chinese) 李徳, 劉邦斗, 雷景山：堯頭古鎮, 2015.8

14) Shaanxi Institute of Urban \& Rural Planning and Design: Yaotou Historical and Cultural Town Conservation Plannning, 2013. 6 (in Chinese)

陝西省城鄉規画設計研究院 : 澄城県堯頭歴史文化名鎮保護計画, 2013.6

15) Wu, L.B.: Thousand years of Yaotou's pottery of drawing list, Shaanxi Xinhua Publishing Media Group, 2016.6 (in Chinese) 点来宝 : 千年堯頭窐精品図録, 陝西新華出版伝媒集団, 2016.6 


\title{
THE MODERNIZATION OF CERAMICS INDUSTRY IN CHINESE TRADITIONAL VILLAGES AND ITS IMPACT ON THE HISTORICAL LANDSCAPE
}

Yaotou Village in Guanzhong area of Shaanxi province

\author{
Yujia LIU ${ }^{* 1}$, Yu OKAMURA *2 and Hikari KOMUKAI*3 \\ ${ }^{* 1}$ Ph.D. Candidate, Dept. of Tourism Science, Tokyo Metropolitan University, M.Env \\ *2 Assoc. Prof., Dept. of Tourism Science, Tokyo Metropolitan University, Dr.Eng. \\ ${ }^{* 3}$ Grad. Student, Dept. of Tourism Science, Tokyo Metropolitan University, B.Tourism Science
}

In recent years, the revitalization and development of traditional industries has been taken into account in the preservation of traditional Chinese villages. At the same time, it is necessary to consider the impact of modernization on traditional industries, such as lifestyle changes, mechanization of production facilities, and tourism development. In this study, we selected Yaotou Village in Shaanxi Province as a research subject, which developed greatly in the traditional pottery industry during the Ming and Qing dynasties. The purpose of this paper is to clarify the modernization of the actual status of the production environment of the revitalized traditional pottery industry, methods of making pottery, types and designs, distributions, and sales methods. In addition, its influence on the historical landscape is clarified.

The following three points of revitalized pottery are clarified by field surveys and interviews with eight potters.

1) Due to changes in the management form of pottery since its revitalization, the site scale and use of kiln caves have changed from the past, but the spatial structure and architectural style in this region have been inherited.

2) On the one hand, local soil and production processes have been inherited. On the other hand, pottery facilities, tools, and work-sharing have become reasonable, and the types and designs of pottery have changed to adapt to people's modern lifestyles.

3) Potteries in this village are sold and circulated by appropriate methods such as modern communication and tourism.

In addition, we found that pottery contributes extensively to the preservation of the historical landscape in this village, such as conversion and reuse of related pottery facilities in the conservation of historic buildings, restoration of buildings by using traditional materials and construction methods, and new buildings in harmony with the historical landscape.

Moreover, we also found that the unique features could be regarded as a cultural landscape, such as smoke from kilns during the production process and the lively atmosphere of the old street due to sales and distribution. 